\title{
Literacy Practice in Vocational Engineering Education: Is It Necessary? (A Case Study on the Concrete Construction Course)
}

\author{
Anis Rahmawati \\ Faculty of Teacher Training and Education, Universitas Sebelas Maret, Indonesia \\ Jl. Ir.Sutami 36A Surakarta 57126 telp. +62271648939 \\ Hand phone number: +628156855232 \\ e-mail address: anisrahmawati79@gmail.com
}

\begin{abstract}
Literacy skills, both reading, and writing are often regarded as something that is not so important for vocational students to pay attention. In fact, in today's rapid growth of industrial technology, workers are required to have adequate literacy skills that enable them to keep up with the developments. This study aims to investigate how does literacy was practiced in the vocational engineering field. This study was carried out using the semistructured interview. As participants in this study were 4 tutors which taken from Vocational Engineering Education Department. The data collected were the results of the interview, students' field work reports, and the results of field observation on the situation in classroom and workshop. This case study was carried out on concrete construction course. The result from this research sawn that students literacy practise in reading was rarely implemented. A habit of writing manually also rarely done, but students were accustomed to making written work reports with computer technology-based tools. The lack of active reading practice with a good understanding brings difficulties for students to meet the achievement of competencies. Practical students did a lot of misunderstanding on literacy in the form of technical symbols. These were serious problems in engineering field because failure in reading symbols can bring to failure construction.
\end{abstract}

Keywords: Literacy; Vocational engineering; literacy practice; Concrete Construction

\section{BACKGROUND}

The word "literacy" is an unfamiliar term among vocational education students. When the author asked some vocational education students about whether it is literacy? Most of them answered did not know, and a few of them answered literacy is the activity of reading and writing. When they do not know just even what its meaning, even less to understand the purpose of literacy. It is still assumed that the majority of vocational education students, especially in vocational engineering, that literacy exists in the realm of the social field, not for the consumption of those who engage in engineering activities. Vocational education students assume that for them, to be mastery in work skills through practical exercises is 
more necessary than 'just' reading and writing. That majority perspective of vocational education students about the literacy causes the lack of literacy practice culture among vocational education students. Whereas low literacy skills will have an impact on workers' understanding of the health and safety regulations provided to them even their rights to a safe workplace [1].

Vocational education is a stage of education which oriented to the fulfillment of skilled workers to fill the workforce of business and industry [2]. To prepare the vocational education graduates to be ready to take part in the economic growth in a nation and global, the vocational education should provide the provision of work skills and special competence according to their field and supported by the good attitude and social skills [3].

In the current era of information disclosure, the development of science and technology spread rapidly throughout the world. Technology and Information do not have nationalities anymore [4]. With no boundaries of territory or time, information spreads rapidly. Those who respond and absorb quickly will be able to keep up with these developments, taking advantage of these developments more quickly and optimally, so as not to be left behind or underdeveloped. Likewise is the case in the Industry. In order to keep the industry growing, not stage or even die, it must continue to seek development, innovation, improvement in all areas that support its development efforts. The industry needs to keep abreast of the existing scientific and technological developments. Included here are the human resources involved in this industry.

The most rapid spread of science and technology is through literacy, either in writing or in other visual forms such as pictures and videos. If it wants to be able to capture a lot of information, then it takes a lot of literacy. The more accustomed to literacy practices the greater the possibility of capturing information. Because education lies at the heart of economic growth and development [5] so it is necessary to build literacy practise in an education system.

Referring to these conditions, this article is structured to review how literacy practices are currently getting around in the learning process of vocational engineering education. This study was conducted at one of the vocational education institutions in Indonesia, taking a case on Concrete Construction Course. Why did took the concrete construction course as a case example, it was because of the special character of this course. Before students do practice in the workshop to make concrete constructions' workpiece, students must create a mix design concrete in paper-based work plans first. There are various methods that can be done to make mix design concrete. And in the process of preparing the mix design concrete, involving many activities of literacy.

This paper is structured as follows. Author begins by considering the existing literacy condition of Indonesian in general and then focusing on the practices in vocational engineering education. Author, further, consider with the functional literacy in the vocational engineering education field. Since the literacy practices under question are in the case study of concrete construction, the subsequent discussion focuses on literacy in the fields of concrete construction. Author, afterward, consider how the need for literacy in the field of engineering is reflected in students' written reports. 


\section{Existing Literacy Condition of Indonesian People}

8 September was enacted by UNESCO in 1964 as world literacy day. This was so in order to remind people in the world about the importance of literacy habit for the development of civilization. The first materialization of the inherent functionality of literacy is writing something meaningful and then reading it with comprehension [3]. While the literacy definitions according to the International Adult Literacy Survey (OECD, 2005) are the ability to understand and execute written information on daily activities, at home, at work, and in the community, in order to achieve goals and develop knowledge and potential of a person.

Survey of the OECD in 2016 in terms of adult literacy on the aspects of the ability to understand and respond appropriately to written texts shown that less than $1 \%$ of adults in Indonesia attain the highest levels of proficiency (Level 4 or 5) in literacy. At level 4, adults can integrate, interpret and synthesize information from complex or lengthy texts that contain conditional and/or competing for information. Then, only 5.4\% of adults attain level 3 in literacy. Adults performing at this level can understand and respond appropriately to dense or lengthy texts and can identify, interpret or evaluate one or more pieces of information and make appropriate inferences using knowledge text structures and rhetorical devices. Almost $70 \%$ of adults in Jakarta score at or below Level 1 in literacy. Adults at this level are only able to read brief texts on familiar topics to locate a single piece of specific information. To complete such tasks, only basic vocabulary knowledge is required, and the reader is not required to understand the structure of sentences or paragraphs. However, the result from the reading components assessment, the average proportion of reading components items answered correctly ranges from $85.1 \%$ (in sentence processing) to $95.9 \%$ (in word recognition). In other words, most adults are equipped with the foundation skills that are a prerequisite for developing higher levels of literacy proficiency [6].

The Indonesian government continues to improve literacy competence in their communities. Represented by the Ministry of Education and Culture, the government has targeted an average literacy level of $96.10 \%$ and a PISA score of 414 in 2019 [7]. To achieve these targets, the government is developing a School Literacy Movement (Gerakan Literasi Sekolah, GLS) in educational institutions to develop it into a learning organization that keeps all members as lifelong learners.

This movement is carried out to foster learners' reading habits and improve their reading skills, and therefore knowledge can be mastered properly [8]. In the vocational education programs, literacy enhancement is considered a part of the basic competencies to meet industry needs. These efforts are realized with language skill reinforcement of vocational school students as one of the strategic policies to achieve the program of 'Indonesia Smart' [7].

\section{Vocational Education in Indonesia}

Indonesia is currently in the midst of a transition to economic growth based on knowledge and science and improving the competitiveness, growth, and skills of workers. 
However, there are other major obstacles left in the making of skills, including the gap between people skills and the skills needed in the economic sector. Based on the findings of a research carried out by World Economic Forum Global Agenda Council on Employment [9], issues on skill, matching skill and skill mismatching still dominate problems in labor. The government copes with the problems through improvement of education and training systems which orientate towards the need fulfillment of skilled labor and work-oriented programs.

This is to improve work competence and community participation in lifelong learning [10] These efforts are realized by government policy in improving the quality of vocational education, by including subject matter in vocational schools.

Those efforts are brought into reality by government policy in improving the quality of vocational high education, that is by bringing into a line subjects in vocational school (SMK) with major economic activities in the closest center of economic growth and increased access to education and training services by engaging with industry [7].

Supplying skilled labor is one of determining factors for economic growth today. Therefore, the need to train workers to become skilled, critical, and familiar with the technology, is an important issue in many countries to ensure that their citizens are competitive enough in the marketplace in the era of globalization [11]. Multinational companies will look for workers, both local workers from surrounding companies and skilled workers from other parts of the world. Hence, the engineering literacy levels of workers in a certain country will contribute to the up and down of job availability for citizens and the amount of capital investment in that country (National Governors Association, 2008).

Job seeking competition becomes harder, especially for those with limited skills [5]. The number of workers from time to time is getting higher. The number of productive population in Asia in 2050 is predicted to reach 3.4 billion, the highest in the world [12]. According to Lucas, et.al. [13] six generic competencies required for work in 21st century include: (1) routine expertise (being expert in working procedure in his/her domain); (2) resourcefulness (having intelligence to act effectively when needed), (3) functional literacy (including mastery of ICT), (4) craftsmanship (being proud and attentive to work), (5) business-like attitude (understanding social and economic aspects of work), and (6) wider skills for growth (learners are independent to stand firm for continuous improvement). Good literacy competencies will encourage the achievement of those aforementioned competencies.

\section{Characteristics of Vocational Engineering Learning}

Vocational education is one of the types of education focusing on the preparation of learners to have specific competencies, skill, behavior and cooperative attitude, as well as social responsibility, and therefore enabling young generation to take part in the economy, empower social cohesion, and become the responsible citizen [12]. Vocational education is a unique community in the education field. Each vocational field provides special learning environment involving students in the learning process through direct practices, and therefore they are able to develop their competencies according to their fields. The system 
of vocational education in the field of engineering is more likely to pay more attention to skills which have to be mastered by individuals in adapting to existing technology in order to enable them to work productively.

The characteristics of expected outputs from vocational education are: (1) to have professional vocational skill, (2) to have thinking ability, sensitivity, and artistic ability, and to show excellent moral commitment, 3) to have an ability to solve problems in real life, and 4) to have critical thinking ability and ability as an agent of change [2]. Vocational education, basically, prepares learners to be capable of playing important roles in an era of a rapid change of technology. This requires vocational education to orientate not only to train learners to master a certain skill but also to prepare them to have a good adapting ability in the changes of technology and social environment.

\section{Literacy Attitudes in Vocational Engineering Learning}

Most of competencies in the vocational field are arranged in practical subjects. Theories related to practical materials are couched in modules for practices and current reference standards. Practical materials are embodied in certain worksheets arranged by tutors. Most of the practical students directly practice without learning module and standard. When they face difficulties, they ask tutors and then tutors provide explanation and samples through direct practices. Literacy habit has not been integrated with the learning process in vocational education.

The literacy practice of vocational engineering education appears to be receiving quite a less of attention. A few prior studies have been done to investigate it in some areas. Sustainable development solutions network suggested goals for post-2015 there are related to technical and vocational skills, noted the need to develop functional literacy and numeracy skills, and also skills for (decent) work [14]. The students' skill level of visual literacy in architectural education has analyzed by Hare \& Kulog $[15,16]$. They proved that visual literacy can be soon enhanced by means of other branches of art within architectural education. The Syrian university students' electronic literacy practices and the factors that influence these practices were studied by Hallajow [17]. The findings reveal that Syrian university students use a variety of languages in their electronic literacy practices and some technical issues were identified as being factors which influence these practices. Parkinson \& Mackay [18] investigated the literacy practices of trades training in Carpentry and Automotive Technology. They identified that students were faced with spoken language practices which differed from everyday language in being highly technical, and read a wide variety of texts, including complex professional texts. In this study, literacy practices in the vocational engineering field, especially in concrete construction, were reviewed from four basic competencies as four models of literacy according to Freebody and Luke [19].

\section{Literacy Models in Vocational Engineering Field}

Freebody and Luke [19] postulates that effective literacy needs four basic competencies as four models of literacy. Those four competencies are equally important and do not have to be recognized respectively, or hierarchically. The first competence is being able to 
understand the context of the text, which is recognizing and using features like the alphabet, voice, spelling, convention, and text pattern. The second competency is understanding and arranging meaningful text, which is comprehending and arranging written, virtual, and oral texts in the certain culture, institution, family, society, country, etc., and describing a scheme. The third competency is using texts functionally, or in other words, for certain purposes. This is an ability to find out that texts have different cultural and social functions, both inside or outside educational institutions. This function is closely related to how text is composed, intonation for pronouncing text, the degree of formality of text, and the order of text components. The fourth competency is analyzing text critically, which are understanding and acting based on the knowledge that texts are not neutral. Texts represent certain points of view and can influence people's ideas.

\section{METHODOLOGY}

\section{Research Design}

In order to investigate vocational engineering literacy practices, the research was carried out using semi-structured interviews.

\section{Participants}

Four tutors from one of Vocational Engineering Education Department in Indonesia were nominated as the participants in this study. Tutors taking part in this study met the inclusion criteria: had already taught in engineering vocational field especially in concrete construction for 10 years at the minimum. We regard the tutors as expert informants, who, besides having teaching experience for a number of years, they were also have worked as professionals in concrete engineering trades, or have some research program focused in the concrete engineering field. They have both an expert's insight into the literacies as well as a tutor's insight into the aspects of that literacy that are problematic for students. The research objectives were explained to participants and later participants were interviewed individually by the researcher.

Tutors are expected to provide information about all literacy tasks students engage in, some efforts which tutors have done to familiarize students with literacy in written, read, or spoken, as well as the difficulties students encounter in literacy.

\section{Procedures}

In-depth interviews were carried out with each tutor. Open questions were posed to tutors. This approach was selected to get a broad and inclusive idea of all literacy tasks students engage in, in the first instance, without limiting the focus by referring to specific contexts or genres. This allowed the interviewer to ask more specific questions in response to information that each tutor provided. 
The first interview focused on the educational background of each participating tutor, including working experience in engineering. Additional information includes experiences in improving literacy, both general and particular engineering ones. The following interview focused on tutors' experiences in observing recent students' literacy practices in concrete construction. Literacy practices seen from reading and writing activities are related to particular tasks according to learn engineering field. Information obtained was student's difficulty in understanding literacy in engineering field during learning and when practicing in real working life.

Each interview required approximately 90 minutes for each tutor. During the interview process, the researcher took brief notes of participants' responses to help her arrange interview transcript and quickly make identification whether further questions were required. Moreover, students submitted reports as descriptions of literacy practices they had performed along with difficulties they faced.

\section{Data Analysis}

Data were analyzed through three stages comprising data reduction, data presentation and conclusion [20]. Data resulted from interviews with tutors were transcribed. The transcripts of interviews were read repeatedly to obtain the parts needed which showed literacy practices in concrete construction and difficulties in understanding literacy in this field faced by students. Transcripts of interviews with all tutors were then coded and analyzed qualitatively to obtain agreement on the identification of practices and obstacles in vocational engineering literacy. Data analyses to identify literacy practices in vocational engineering field along with difficulties were summarized in the table. Students' reports and field observational reports helped support the reliability of data on the results of the analysis.

\section{RESULTS AND DISCUSSION}

The basic competencies of literacy in this article were observed using four literacy models based on Freebody \& Luke [19], including the ability of recognizing and using text patterns and features, the ability of composing written and oral texts along with drawing schemes, the ability of using texts for specific purposes, and the ability of analyzing texts. The relation between each literacy basic competence and related activities observed in this research was composed in Table I. 
TABLE I. THE RELATION OF LITERACY BASIC COMPETENCES AND RELATED ACTIVITIES

\begin{tabular}{ll}
\hline \multicolumn{1}{c}{$\begin{array}{c}\text { Literacy basic } \\
\text { competence }\end{array}$} & \multicolumn{1}{c}{$\begin{array}{c}\text { Related activities } \\
\text { (that support literacy practice) }\end{array}$} \\
\hline $\begin{array}{l}\text { Recognizing and } \\
\text { using text patterns } \\
\text { and features }\end{array}$ & $\begin{array}{l}\text { Reading literatures and standards to apprehend the concept } \\
\text { of technology, to understand the uses and the risks of } \\
\text { technology; and to solve problems related to technology }\end{array}$ \\
\hline $\begin{array}{l}\text { Composing written } \\
\text { and oral texts along } \\
\text { with drawing } \\
\text { schemes }\end{array}$ & $\begin{array}{l}\text { Composing written work plans containing procedures, } \\
\text { pictures, diagrams, tables and schemes in accordance with } \\
\text { the purposes to achieve the goals }\end{array}$ \\
\hline $\begin{array}{l}\text { Using texts for } \\
\text { specific purposes }\end{array}$ & $\begin{array}{l}\text { Using texts in the field of vocational engineering based on } \\
\text { their functions, i.e. for asking questions, making decisions, } \\
\text { as well as solving problems related to engineering } \\
\text { vocational subjects }\end{array}$ \\
\hline Analyzing texts & $\begin{array}{l}\text { Understanding literatures and standards in the field of } \\
\text { vocational engineering based on the context of each } \\
\text { technology }\end{array}$ \\
\hline
\end{tabular}

Thus, vocational engineering students draw on a wide range of sources in learning and using some activities to support basic literacy competencies achievement. Furthermore, the discussion focused on the current literacy practices in concrete construction. The comments here are based not only on interviews from Jack, August, Janti, and Erica, four of the concrete construction tutors but also on a small corpus of 10 students' final reports.

\section{The Engineering Literacy Profiles of the Instructors (Informants)}

Before working as a full-time concrete construction instructor, 41-year-old Erica was an employee in a building construction since 1998. The projects she constructed were various, including steel construction, concrete construction, and wood construction. Meanwhile, she has been an instructor in concrete engineering since 2003. Her practical experiences help her give instructions to students. She develops her theoretical knowledge about concrete construction by reading books, journals, as well as video from internet sources.

August, 47 years, has been an instructor in building engineering with specialization in concrete construction since 2000. His educational background is a master in Civil Engineering and thus, his theoretical understanding in concrete construction is good. His knowledge of concrete construction plan was gained merely from theoretical knowledge, and from many research programs which he conducted in the concrete engineering field.

Janti, 37 years, has been an instructor of concrete construction since 2005. Her education background is Civil Engineering. She is qualified in mastering the theory of concrete construction plan. Janti learns about concrete construction from formal studies and books, recent standards as well as research journals. Janti conducted some research project in concrete construction which brings her understanding and skill in this field improved properly. 
Jack, 41 years, has been a concrete construction instructor since 2005. His educational background is a master in Civil Engineering. In order to improve his knowledge in concrete engineering, he learns independently from books. Besides his activity as an instructor, he also conducts some projects in concrete construction for roads, bridges, and buildings. The combination of theoretical and practice become a good competence for him in conducting vocational practice in concrete construction.

\section{Students' Literacy Practices in Recognising and Using Text Patterns and Features in Concrete Construction}

Based on the interviews with tutors, concrete construction work in vocational engineering course consisted of two main parts, namely the manufacture of reinforcement and manufacture of concrete mix. Making reinforcement required detailed engineering design based on the needs of reinforcement from the calculation results of structures and required materials. Meanwhile, the mix design concrete was made on the basis of the results of mixture planning with a certain method. The planning stage was to practice basic literacy competencies to analyzing text as well as to recognize and use text patterns and features through a variety of activities to dig up information about the terms and procedures of planning concrete reinforcement and concrete mixture from the standard of planning reinforced concrete and text books on concrete structures.

There were several kinds of methods for designing concrete mixes which applicable in concrete industry. Each method has its own function and purpose. Many concrete textbooks present the methods. But, according to Jack, one of the concrete construction tutors, the students in this study merely studied the steps through a module of best practice guidelines prepared by tutors when making mix design concrete. However, students did not develop methods and focused on those provided in the module. Consequently, when faced with concrete planning that has different functions and objectives as exemplified in the module, they have difficulty working on it.

There are many special symbols involved in the concrete construction. Each symbol has its own meaning, related to its application in the field. The construction worker's mastery of the meaning of each symbol becomes the key to the correctness of the design application in real construction. Here will seem the importance of functional literacy skills in the workplace. It is obvious that an individual cannot possess good employability skills without an adequate level of literacy, especially in functional literacy [21]

Janti:" We did an oral response to assess how much students' understanding of concrete construction procedures they have worked on before. Practical students' responses indicated practical students' misunderstanding on engineering literacy in the form of technical symbols in concrete construction field, for examples, defining the symbols on steel reinforcements and interpreting the meaning of cross-sectional images of reinforced concrete columns"

The misunderstanding on engineering literacy will bring serious problems in the engineering field, as well as in concrete construction. Although engineering is typically regarded as technical work, in reality, it is a form of communication. Engineers communicate their vision of a structure and how it should perform through drawings and 
specifications [22]. Thus, failure in reading drawings and specifications put dangerous technical errors which impact on the real situation of construction application.

Be able to read and understand basic texts - drawing out relevant information is one of the abilities that must be possessed by an individual to be a functionally literate person [21] A functionally literate person is who can engage in all those activities in which literacy is required for effective functioning of his group and community and also for enabling him to continue to use reading, writing and calculation for his own and the community's development [3].

Sustainable development solutions network suggested goals and targets there are related to technical and vocational skills for post-2015 that are all youth and adults have access to continuous lifelong learning to acquire functional literacy, numeracy, and skills to earn a living through decent employment or self-employment [14]. As an educational institution which focuses on preparing their graduates for works, vocational education need to equip their students with the literacy skills required for the workplace.

\section{Students' Literacy practices in composing written and oral texts along with drawing schemes in concrete construction}

Based on the interviews with tutors, in the planning stage students also practiced their ability to compose written texts, namely to create a written plan containing calculations, working steps, pictures, diagrams, tables and schemes created in accordance with the purposes to achieve the goals.

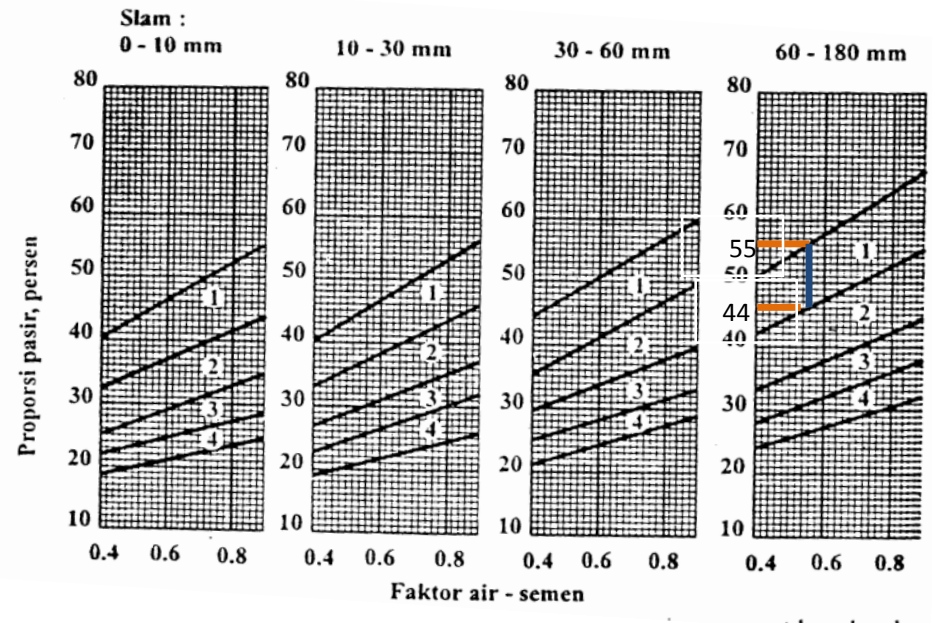

Source: Students' practical work reports on concrete construction, produced from SNI (Indonesian National Standard) of 03-2847-2002

Figure 1. Sample diagram of mix design concrete

Figure 1 represented how practical students connected multiple conditions of the planned concrete mix, including slum, cement water factor, and fine aggregate gradation, 
into a chart to make the proportion of fine aggregate with coarse aggregate in the mix concrete. The chart was obtained from existing standardized documents. According to tutors, these steps still required intensive guidance.

Be able to write with legible handwriting is also one of the abilities that must be possessed by an individual to be a functionally literate person. Even though speaking and listening contribute significantly to what is defined more broadly as employability skills [21], but reading and writing become the important skills in the context of vocational engineering, as well as vocational construction engineering. Civil engineers must be able to communicate technical design through writing the detailed engineering design in the forms of drawings and specifications, and then the construction workers must be able to read that design and transfer them into technical construction work.

After completing the practice of making the workpiece in the workshop, students prepare a written report. From the small corpus of 10 students' final reports, it is shown that here, students were practicing literacy basic competence in composing written text along with drawing schemes. The report was prepared based on experience when carrying out work practices. From the field observation on the situation in the workshop, during in the process of manufacturing concrete construction, tutors kept accompanying practical students and guiding them, and therefore, the workpieces could be successfully produced as expected.

Oral presentations on the implementation and the results of work were made at the end of learning activities. From the field observation on the situation in the classroom during the presentation time, it is shown that through these activities, practical students were accustomed to communicate actively and effectively.

Vocational students need to master the ability to oral communicate as one of workplace skill. Communication skills are also a key factor to improve the ability of vocational leavers to obtain a job. Being understand with oral communications, react appropriately, and be sufficiently articulate to communicate orally were part of an individual must be able to be functionally literate [21]. Oral communication skill and writing skill often used together in the construction workplace. Talk, as oral communication, in the construction's workshop or on site often accompanied by sketches planning out work to be done and others visual elements such as isometric drawings, or as calculations of costs involved in doing work depicted in diagrams [23].

\section{Students' Literacy practices in Using Texts for Specific Purposes in concrete construction}

Based on the in-depth interviews with the tutors, related activities that support basic literacy competence of using texts for specific purposes were performed in the activity of understanding the meaning contained in concrete construction course books according to their functions. These books consist of many symbols or patterns which are specially applied in concrete technologies. Reading of concrete course books as well as another engineering course book, students force to interact with texts in complex ways. In order to understand the meaning of the text, readers must pay attention to text and some diagrams in the same time. 
The ability to use text for specific purposes were practiced through a mix design concrete that involving the use of symbols and special formula in the field of concrete construction. Then students will apply that symbols and formula in their written reports. These activities made use patterns and numbers in structure calculation, pictures and specific symbols in concrete construction, and numbers showing the work device dimensions.

August: "The written reports prepared by students are usually quite complete, detailed, and good organized. The tutor's module is helpful in preparing reports"

Writing ability of vocational engineering education leavers through literacy practice in Using Texts for Specific Purposes needed so that construction workers will content with the adequate level of proficiency with writing engineering literacy skill. Because when already in the workplace, qualified construction workers professionals write a widely varied range of genres including orders, reports on jobs or buildings and Builder's Diaries [18].

\section{Students' Literacy practices in Analyzing Text in concrete construction}

Erica, another of concrete construction tutor, stated that practical students still relied heavily on guidance from the tutors, both in the planning and execution of the manufacture of the workpiece. Although the theory of computation for planning concrete structure had been learned in the previous semester, they still found difficulties when planning the calculation of mix design concrete for the workpiece project they prepared. During theory learning, many quantities were assumptions. Meanwhile, in a project that they would practice, quantities were suitable with the actual conditions in the field. Most of the practical students had not been able to seek an adjustment between theory and real condition of the workpiece made. Failure to translate a field condition into a planning concept will have an impact on planning errors.

This condition indicated that vocational student's skill of engineering literacy has not been properly mastered. The research found from this study indicated that vocational students still have difficulties in analyzing text based on the context of concrete technology. Tutors still found there was misreading chart which will make the steps in the planning process goes wrong. Wrong planning, of course, makes the results of the planning is no longer in accordance with the conditions set previously. It was a fatal condition in engineering.

Reading with understanding the basic text - drawing out relevant information is a must ability to be functionally literate. Reading literacy refers to being able to comprehend the contents properly, find both explicit and implicit meanings, analyze the content and the information obtained, and being able to interpret the content properly and pass it on [24]. Vocational leavers can begin to use their other skills and abilities to contribute in the workplace if the literacy skill is effectively addressed [21].

There are a number of recommendations as a result of this research. An updated functional literacy survey of the Indonesian Vocational Education leavers should be conducted as a matter of urgency. A more widespread awareness campaign around the importance of increasing functional literacy skills in all vocational institution is advised. 
There is a relationship between increasing levels of language, literacy and numeracy proficiency and positive outcomes, such as improved economic performance and social cohesion [25]. Therefore, the efforts to improve literacy skills of the workforce need to receive attention from governments, educational institutions, as well as industry. Governments and others who are seeking to sponsor adult literacy can play an active role through business interaction activities in the classroom or in the workshop[26]. Through these activities, what was being taught would be seen as relevant and can help to produce a better understanding of students in the professional trade. The integrated curriculum between education institution and workplace will enhance the acquisition of literacy.

\section{CONCLUSION}

The research findings on literacy practices in engineering vocational field indicate that basic competencies of engineering literacy in recognizing and utilizing text patterns and features still need to be improved. A habit of reading the existing planning standards is rarely implemented. Though considered better, textbook reading habit related to the area of expertise also requires improvement. Ability in composing written texts and using texts for specific purposes have been well implemented through planning mix design concrete and arranging practical implementation reports, which are commonly done using a calculationassisted tool and writing tools. Practices dealing with the ability to analyze texts have been implemented in some activities, like searching for information relevant to workpieces which will be produced, through modules and other sources. In addition, interpreting data resulted from measurement activities have been carried out. However, the literacy practice still has to be improved, especially getting students familiar with solving problems related to technology through available texts, like manuals. The conclusion of this article is that the literacy practice needs to be familiarized with students in technical vocational education to avoid errors in the execution of work that can be fatal to the construction and at the same time make them lifelong learners.

Notes: All names quoted are pseudonyms.

\section{REFERENCES}

[1] Campbell, A. All Signs Point to Yes Literacy's Impact on Workplace Health and Safety. 2008.

[2] Wagiran. "Mewujudkan Paradigma Vocational Education For All (VOEFA) Melalui Strategi Kerjasama Sinergis". INTERNATIONAL SEMINAR Reformulating the Paradigm of Technical and Vocational Education, pp. 512-520. 2012.

[3] Bhola, H. S., Education, V. "Functional Literacy, Workplace Literacy and Technical and Vocational Education : Interfaces and Policy Perspectives". 1995.

[4] PSAROUTHAKIS, J. "These 15 charts illustrate the current U . S . private equity ...". http://businessthinker.com. 2010.

[5] Sondergaard, L., Murthi, M., Abu-Ghaida, D., Bodewig, C., Rutkowski, J. Skills , Not Just Diplomas Managing Education for Results. Washington DC: the World Bank. 2012. 
[6] OECD. Education at a Glance 2016. OECD Publishing. OECD Publishing. 2016. DOI:10.1787/eag2016-en[7] The Ministry of Education and Culture of Indinesia. Indonesia Education Strategic Plan 2015-2019. 2015.

[8] DitPSMK. PANDUAN GERAKAN LITERASI SEKOLAH DI SEKOLAH MENENGAH KEJURUAN. Jakarta: DIREKTORAT PEMBINAAN SEKOLAH MENENGAH KEJURUAN. 2016.

[9] Klosters, D. Matching Skills and Labour Market Needs: Building Social Partnerships for Better Skills and Better Jobs. Global Economic Forum. 2014. Retrieved from http://www3.weforum.org/docs/GAC/2014/WEF_GAC_Employment_MatchingSkillsLabourMarket_ Report_2014.pdf

[10] And, U.-U. I. C. for T. and V. E., Training. World TVET Database Indonesia. 2013.

[11]Friedman, B. T. L., Friedman, T. The World Is Flat 3 . 0 : A Brief History of the Twenty-first Century Pricing \& Availability: Additional Details: (1st Picado.). New York: Picador/Farrar, Straus and Giroux. 2007.

[12]Wang, Y. Education in a Changing World: Flexibility, Skills, and Employability (Vol. 69104). Washington DC. 2012.

[13]Lucas, B., Spencer, E., Claxton, G. "How to teach vocational education : A theory of vocational pedagogy". Centre for Real-World Learning, University of Winchester, (Dec), pp. 133. 2012. Retrieved from http://www.skillsdevelopment.org/PDF/How-to-teach-vocational-education.pdf

[14] Palmer, R. "Technical and vocational skills and post-2015: Avoiding another vague skills goal?". International Journal of Educational Development, 39(June 2013), pp. 32-39. 2014. DOI:10.1016/j.ijedudev.2014.08.007

[15] Kilıçaslan, H., Kuloglu, N. "Visual Literacy during the Period of Architectural Education". Procedia Social and Behavioral Sciences, 191, pp. 2824-2828. 2015. DOI:10.1016/j.sbspro.2015.04.711

[16]Hare, K., Kulog, N. "Visual Literacy During The Period of Architectural Education". Procedia Social and Behavioral Sciences, 191, pp. 2824-2828. 2015. DOI:10.1016/j.sbspro.2015.04.711

[17] Hallajow, N. "The interplay of technology and context in Syrian university students' electronic literacy practices". Computers in Human Behavior, 55, pp. 178-189. 2016. DOI:10.1016/j.chb.2015.08.050

[18] Parkinson, J., Mackay, J. "The literacy practices of vocational training in Carpentry and Automotive Technology", 6820(March). 2016. DOI:10.1080/13636820.2015.1104714

[19] Freebody, P., Luke, A. Literacy as engaging with new forms of life: The "four roles" model. (G. Bull \& M. Anstey, Eds.) (The Litera.). Sydney: Prentice Hall. 2003.

[20] Miles, M.B. \& Huberman, A. M. Qualitative Data Analysis (2nd ed.). London: Sage. 1994.

[21] Macey, E. "Employers' views on youth literacy and employability", pp. 1-13. 2013. Retrieved from http://www.literacytrust.org.uk/assets/0001/7766/Employer_perspective.pdf

[22] Delatte, N. "Failure literacy in structural engineering". Engineering Structures, 32(7), pp. 1952-1954. 2010. DOI:10.1016/j.engstruct.2009.12.015

[23] Holmes, J., Woodhams, J. "Building interaction: The role of talk in joining a community of practice". Discourse \& Communication, 7(3), pp. 275-298. 2013. DOI:10.1177/1750481313494500

[24]Delgadova, E. "Reading Literacy as One of the Most Significant Academic Competencies for the University Students". Procedia - Social and Behavioral Sciences, 178(November 2014), pp. 48-53. 2015. DOI:10.1016/j.sbspro.2015.03.145

[25]Circelli, M., Curtis, D., Perkins, K. "Mapping Adult Literacy Performance. Background Paper.". National Centre for Vocational Education Research (NCVER). 2010. Retrieved from http://eric.ed.gov/?id=ED528177

[26] Shiohata, M., Pryor, J. "Compare: A Journal of Comparative and International Education Literacy and vocational learning: a process of becoming", (October 2014), pp. 37-41. 2008. DOI:10.1080/03057920701419967 